Fire and Invasive Plants Special Feature

\title{
Climate Change in Western US Deserts: Potential for Increased Wildfire and Invasive Annual Grasses
}

\author{
John T. Abatzoglou ${ }^{1}$ and Crystal A. Kolden ${ }^{1,2}$ \\ Authors are ${ }^{1}$ Assistant Professor, Department of Geography, University of Idaho, Moscow, ID 83844, USA; and ${ }^{2}$ Research Associate, \\ Program for Climate, Ecosystem, and Fire Applications, Desert Research Institute, Reno, NV 89512, USA.
}

\begin{abstract}
Anthropogenic climate change is hypothesized to modify the spread of invasive annual grasses across the deserts of the western United States. The influence of climate change on future invasions depends on both climate suitability that defines a potential species range and the mechanisms that facilitate invasions and contractions. A suite of downscaled climate projections for the mid-21st century was used to examine changes in physically based mechanisms, including critical physiological temperature thresholds, the timing and availability of moisture, and the potential for large wildfires. Results suggest widespread changes in 1) the length of the freeze-free season that may favor cold-intolerant annual grasses, 2) changes in the frequency of wet winters that may alter the potential for establishment of invasive annual grasses, and 3) an earlier onset of fire season and a lengthening of the window during which conditions are conducive to fire ignition and growth furthering the fire-invasive feedback loop. We propose that a coupled approach combining bioclimatic envelope modeling with mechanistic modeling targeted to a given species can help land managers identify locations and species that pose the highest level of overall risk of conversion associated with the multiple stressors of climate change.
\end{abstract}

\section{Resumen}

El cambio climático antropogénico supone que habrá una propagación de la gramíneas anuales invasivas en los desiertos del oeste de Estados Unidos. La influencia del cambio climático en futuras invasiones depende tanto de la capacidad de clima que define un rango potencial de las especies y los mecanismos que faciliten las invasiones y sus reducciones. Una serie de proyecciones del clima para la mitad del siglo 21 se utilizaron para examinar los cambios basados físicamente. Se incluyeron los umbrales de temperatura fisiológica crítica, el tiempo y la disponibilidad de la temperatura, así como la posibilidad de grandes fuegos sin control. Los resultados sugieren cambios generalizados en 1) la duración de la temporada libre de heladas que pudiera favorecer especies de gramíneas anules que no toleran el frio, 2) Cambios en la frecuencia de inviernos húmedos que pueden alterar el potencial para el establecimiento de gramíneas anuales invasivas, y 3) un inicio más temprano de la temporada de incendios así como el alargamiento en la oportunidad durante las condiciones son propicias para el inicio del fuego y el crecimiento de especies invasivas que fomentan la retroalimentación del fuego. Proponemos un enfoque mutuo combinando la cobertura del modelaje bioclimático con el modelo mecanístico dirigido a especies especificas. Esto puede ayudar a los manejadores de los recursos a identificar lugares y especies que representan el mayor riesgo de conversión asociada con los múltiples factores estresantes del cambio climático.

Key Words: Bromus, drought, global climate models, Pennisetum

\section{INTRODUCTION}

Arid and semiarid ecosystems across the western United States face widespread ecological alteration as a consequence of global climate change (Archer and Predick 2008). Projections suggest an acceleration in the rate of climate change across the western United States throughout the 21st century, yielding pressing concerns over the reliability of future water supplies (e.g., Mote et al. 2005), incidence of wildfire (e.g., Westerling et al. 2006), and the stability of natural resources and fragile ecosystems (e.g., Adams et al. 2009). A chief concern in the arid and semiarid rangelands of the western United States is the rapid conversion of shrublands and desert into annual

\footnotetext{
Correspondence: John T. Abatzoglou, Dept of Geography, University of Idaho, Moscow, ID 83844, USA. Email: jabatzoglou@uidaho.edu

Manuscript received 13 October 2009; manuscript accepted 8 March 2011.
}

grassland through the spread of invasive annual grass species (Mack 1981; Brooks and Esque 2002; Bradley and Mustard 2005), and the negative impacts this conversion will have on wildfire regimes, surface hydrology, and loss of critical habitat for threatened and endangered species (Brooks et al. 2004; Wilcox and Thurow 2006). While the encroachment of invasive annual grasses throughout rangelands of the western United States is of concern even in the absence of climate change, direct and indirect impacts of climate change are hypothesized to hasten the rate of land-cover conversion, resulting in an increasingly challenging problem for land and resource managers (Scheffer et al. 2009).

The deserts of the western United States are characterized by a high diversity of floral and faunal species adapted to arid niches (Ricketts et al. 1999). Over the past three decades, there has been a significant increase in the abundance and extent of invasive annual grass species in the Southwest, including 
cheatgrass (Bromus tectorum) across the Great Basin Desert (Bradley and Mustard 2005), red brome (Bromus rubens) across the Mojave Desert (Brooks and Berry 1999), and buffelgrass (Pennisetum ciliare) across the Sonoran Desert (Betancourt 2007). This change has coincided with an increase in the number of large fires and area burned across the arid and semiarid western United States that have been linked to the increased presence of invasive annual grasses (Whisenant 1990; Brooks et al. 2004), wildfire management (Swetnam et al. 1999), and climate change (Westerling et al. 2006). While the forested uplands of the Southwest have historically experienced frequent wildfires (Swetnam and Betancourt 1990), fire is historically rare in the desert shrublands and grasslands because of insufficient fuels to carry surface fire (Humphrey 1974; Schmid and Rogers 1988; Brooks and Matchett 2006; Mensing et al. 2006). Invasive annual grasses not only increase fuel continuity and loading (Brooks et al. 2004) but also are lighter, flashier fuels with lower fuel moistures that cure earlier in the growing season and increase wildfire potential compared to the dense, waxy shrubs and cacti native to the deserts.

Evidence and implications of climate change on the spread of invasive annual grasses are poorly understood and have only recently begun to be addressed comprehensively at landscape scales. These studies are constrained by limited geographic data on the spread of invasive species, resulting in a diminished ability to quantify and model the factors contributing to invasive species expansion. Evidence suggests, however, that observed changes in climate have assisted in invasions across the deserts of the western United States both directly through changes in temperature and precipitation and indirectly through their influence on wildfire. First, warming across the Southwest over the 20th century (e.g., Fig. 1a for the Sonoran Desert in the United States) has extended the length of the frostfree season (Weiss and Overpeck 2005), therein increasing climatically suitable ranges for cold-intolerant species such as $B$. rubens and P. ciliare. Second, while precipitation variability is inherent in the Southwest, a significant increase in coolseason (November-March) precipitation variability over the past half century (e.g., Fig. 1b for the Sonoran Desert) may be responsible for assisting the colonization of invasive annual grasses and increasing fine fuel loading. Finally, increased temperature and reduced humidity during spring and summer associated with recent protracted drought conditions since 2000 (Weiss et al. 2009) have doubled the frequency of extreme fire danger (e.g., Fig. 1c for the Sonoran Desert), resulting in an earlier start and lengthening of the fire season. Although some of these changes (e.g., increasing temperature) are attributable to anthropogenic climate change, it is important to note that other observed changes (e.g., precipitation variability and timing) are likely products of natural modes of climate variability (e.g., Archer et al. 2008).

To date, projections of future invasion potential have primarily focused on predicting future species distributions using bioclimatic envelope modeling (Pearson and Dawson 2003). These studies relate the current extent of a given species with climate normals through empirical relationships based on the presence or absence of the species and then project its future potential extent using climate projections from global climate models (GCMs; e.g., Bradley 2009; Bradley et al. 2009). Bioclimatic modeling results in a static map projecting the
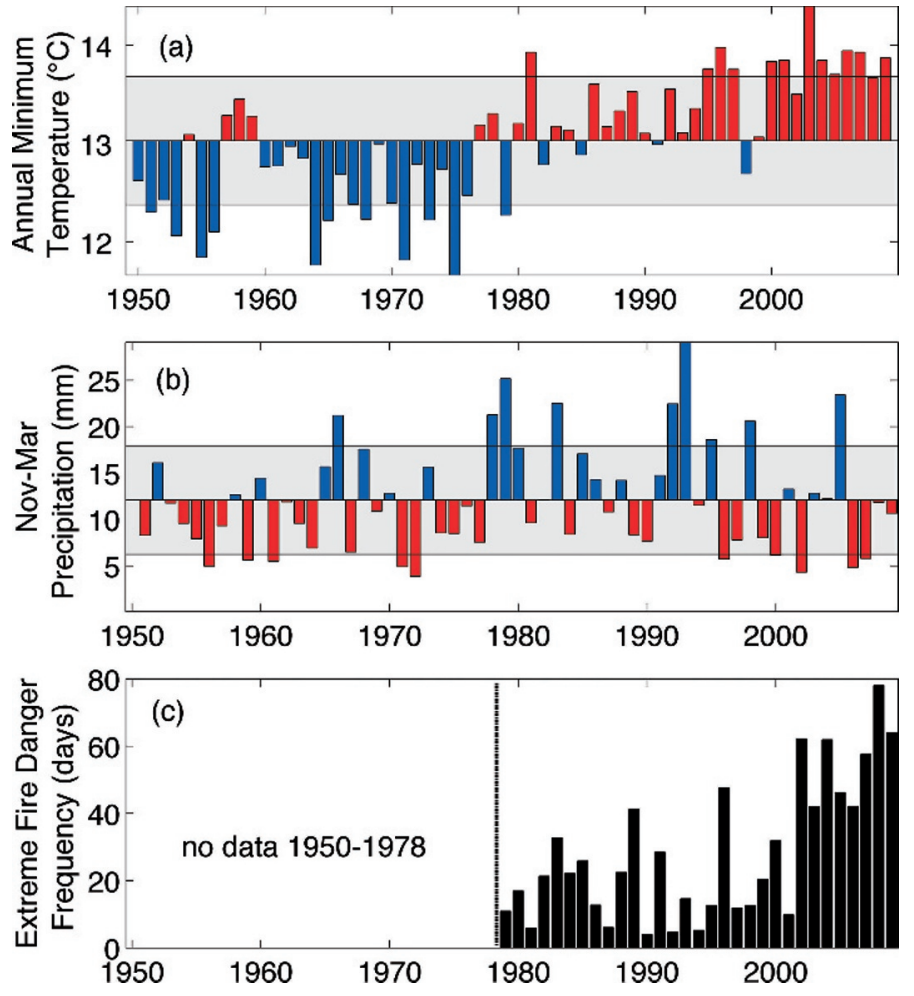

Figure 1. Time series of a, annual averaged minimum temperature from 1950 to 2009. b, November-March precipitation from 1951 to 2009. c, Annual frequency of extreme fire danger quantified as exceeding the historical 90th-percentile Energy Release Component (ERC) fuel model G from 1979 to 2009 aggregated across the Sonoran Desert in the United States. The gray bars in $\mathbf{a}$ and $\mathbf{b}$ make up one standard deviation from the mean calculated from the period of record. Note that no data are available in c prior to 1979, as signified by the dashed vertical line. Temperature and precipitation data are from PRISM (http://www.prism. oregonstate.edu), while meteorological data used in ERC calculations are from Abatzoglou and Brown (2009).

climax stage of a potential invasion at a given time but overlooks the dynamic complexities of the ecosystem that facilitate spread. While bioclimatic envelopes are useful for forecasting stable climax stage biotic communities such as forest ecosystems (e.g., Rehfelt et al. 2006), they may be ill suited to predicting future habitat suitability for water-limited communities in areas of large variability in moisture availability.

What bioclimatic envelopes fail to address are the mechanisms conducive to the expansion and contraction of invasive grasses at interannual and multiyear time scales. These mechanisms include events initiated or enabled by atmospheric forcing, including drought and pluvial periods, discrete precipitation pulses, biophysically relevant temperature thresholds, and disturbance associated with wildfire and flooding. For example, arid and semiarid ecosystems are particularly sensitive to moisture availability and timing. The ability for invasive annual grasses (e.g., Bromus spp.) to commandeer scarce water resources makes them opportunistic to precipitation events (e.g., Mack and Pyke 1983) and resilient during longer dry periods. Wildfire is a catalyst that promotes invasion through a positive feedback process. This process is characterized by the accumulation of an abundant seed bank of invasive annual grass species, a wildfire removing the native perennial 
species, and increases in fine fuel loading and fuel connectivity following landscape conversion to invasive grasses that, in turn, increase fire frequency and inhibit the regeneration of native species ill adapted to fire (Melgoza et al. 1990; Whisenant 1990; Brooks et al. 2004; Keeley 2006).

Events associated with anomalous weather or climate regimes are particularly important from a management perspective, as they provide spatially and temporally defined targets for management intervention. For example, efforts to control the spread of $P$. ciliare may be scaled up to suppress the emergence new communities following precipitation events (e.g., Ward et al. 2006), while prescribed fire for eradication of invasives can be timed to phenology (a climate-dependent characteristic) to maximize effectiveness (DiTomaso et al. 2006). As catalyst events (i.e., wildfire) are incorporated into current management approaches, efforts to examine the response of invasive annual grasses to climate change should address mechanisms of population biology and dispersal. Along these lines, Bradley et al. (2010) suggest merging mechanistic models alongside bioclimatic envelope models to help predict invasion fronts in a changing climate.

The western United States has been identified as a region expected to undergo significant changes in climate over the 21st century, including increases in temperature (e.g., Intergovernmental Panel on Climate Change [IPCC] 2007), aridity (Seager et al. 2007), and moisture variability (e.g., Diffenbaugh et al. 2008). The primary objective of this article is to address the impetus of climate change on processes that facilitate the establishment of invasive annual grasses and community structure in the arid and semiarid western United States. To do this, we examine climate change through the lens of both climate normals as well as higher-order climate statistics, including interannual precipitation variability and critical biophysical temperature thresholds. We also consider the influence of climate change on large fire potential, framing climate change as a catalyst in the fire-invasive feedback cycle.

\section{METHODS}

Landscape-scale approaches to ecological problems require spatially and temporally consistent datasets. Limited long-term, high-quality meteorological observations across the study area mandate an alternative approach to examining the effect of climate change. We used a gridded meteorological dataset and suite of climate models to examine changes in a set of climate features projected for the mid-21st century. The gridded meteorological dataset used here is both of high spatial (8$\mathrm{km}$ ) and temporal (daily) resolution and covers the continental United States from 1979 to 2009 (Abatzoglou and Brown 2009). The data set provides daily maximum and minimum temperatures and relative humidity, daily accumulated precipitation and precipitation duration, and temperature, relative humidity, wind velocity and state of the weather for 1300 local time, all variables needed to produce metrics of fire danger in the National Fire Danger Rating System (NFDRS; Deeming et al. 1977).

GCMs are the primary tool used to project future climate conditions. However, several hurdles must be addressed to incorporate climate projections from GCMs into assessments of regional climate change impacts. The first hurdle is the inherent scale mismatch between the spatial resolution of GCMs (two degrees) and the finer scale needed for local impact assessment. High-resolution climatic information in regions of strong climatic gradients such as the western United States are of critical importance in identifying potential habitat ranges and thus climate impact assessments (e.g., Kriticos and Leriche 2010). Here, a statistical downscaling technique called the Multivariate Adaptive Constructed Analogues (MACA) method was applied to bridge the gap between GCMs and scales usable for decision making (Abatzoglou and Brown 2011). This method uses quantile-mapping bias correction and commonality of patterns (i.e., analogs) between coarse-scale observed daily meteorological fields and coarse-scale daily GCM meteorological fields.

The second hurdle is accounting for the range of projections from various models. More than $20 \mathrm{GCM}$ were used in the IPCC fourth assessment report, each with varying levels of climate sensitivity, resolution, and parameterizations (IPCC 2007). A probabilistic approach that utilizes a range of GCMs is preferred over that of a single model not only to increase the robustness of results (i.e., not relying on the outcome of any single model) but also to provide decision makers with a range of projected changes (e.g., worst-case scenarios). We used daily output from the 13 GCMs that provided daily output of variables required for the period 1971-2000 from the 20thcentury coupled simulations $(20 \mathrm{C} 3 \mathrm{M})$ and for the middle of the 21st century (2046-2065) from the middle-of-the-road emission scenario (SRES-A1B). GCM output was then downscaled using the MACA method, resulting in high-resolution weather scenarios for a modern (1971-2000) period compatible with the historical observations and projected (2046-2065) period.

Downscaled daily weather fields were examined in two primary contexts. First, projected changes in climate normals and higher-order climate statistics, including cool-season precipitation variability and the length of the growing season, were examined for all GCMs and the multimodel mean. The multimodel mean provides a single depiction of climate change and is often regarded as superior to any single model (e.g., Reichler and Kim 2008), while results from individual GCMs provide a probabilistic range of projections and confidence intervals, making results more useful in impact assessments studies. In this study, we focus on model agreement, defined herein where at least 9 of the 13 models exhibit changes of the same sign. By contrast, model disagreement is defined where a two-thirds majority fails to be realized, thus denoting a greater level of uncertainty. Second, daily data were utilized to examine future fire danger through the Energy Release Component (ERC), a widely used metric from the NFDRS that is a proxy for fuel dryness and fire intensity. ERC is a weather-climate hybrid index that considers the cumulative drying effect of previous daily weather conditions and is a frequently used decision tool in fire management.

As large wildfires preferentially occur during extreme fire weather conditions when fuels are abundant and available to burn (Launchbaugh et al. 2008; Kolden and Brown 2010), we examined two metrics to project future wildfire potential: the frequency of extreme fire danger (hereafter EFD, defined by the 90th-percentile ERC threshold) and the onset of fire season. The 90th-percentile ERC values are designated as critical 
thresholds for fire management planning, as they tend to represent conditions at which initial fire suppression (i.e., "initial attack") becomes ineffective and ignitions will likely become large wildfires. The onset of fire season is defined in this study as the first calendar day that exceeds the historical EFD value for at least three consecutive days, while the EFD frequency is defined as the number of days per year exceeding the historical EFD value. Changes in EFD frequency and the onset of fire season for the mid-21st century were calculated as a difference from the historical period.

\section{RESULTS}

\section{Climate Change Influences on Temperature and Precipitation}

Climate scenarios for the mid-21st century suggest significant warming across the Southwest, with the multimodel mean projecting an annual mean temperature increase of $+2.5-3^{\circ} \mathrm{C}$ $\left(+1.3^{\circ} \mathrm{C}\right.$ to $+5.0^{\circ} \mathrm{C}$ intermodel spread $)$ from the historic period. Geographically, more warming is projected for the Great Basin than southern deserts (Figs. $2 \mathrm{a}$ and 2b). Seasonally, models suggest warming to be amplified during the summer across the Great Basin, particularly in models that exhibit a reduction in summer precipitation. Higher-order statistics of changes in temperature suggest a significant decrease in the number of days where the overnight low drops below freezing and an increase in the length of the freeze-free season (Fig. 2c). For example, in the Sonoran Desert outside Tucson, Arizona, the multimodel mean predicts an average of only $6 \mathrm{~d} \cdot \mathrm{yr}^{-1}$ where the minimum temperature drops below freezing by the middle of the 21st century, a significant decline from the historic $16 \mathrm{~d} \cdot \mathrm{yr}^{-1}$. This reduction increases the freeze-free season by an average of nearly $40 \mathrm{~d}$ and also suggests that nearly $2 \mathrm{yr}$ out of every 5 yr may be void of freezing temperatures. Likewise, projections generally suggest a reduction in the frequency of extreme cold events such that a cold spell that might occur every other year under late 20th century conditions may occur only once per decade by the mid-21st century (not shown).

Projected changes in precipitation are less spatially homogeneous than changes in temperature. Despite disagreement of predicted changes in summer monsoonal precipitation across models, strong agreement exists for cool-season (NovemberMarch) precipitation that features a latitudinal dipole across the deserts, with decreases south of about $37^{\circ} \mathrm{N}$ and increases in the northern sections of the Great Basin (Fig. 2d). This dipole migrates northward throughout spring and into summer, resulting in partially offsetting decreases in precipitation for the northern deserts. As a result, a greater fraction of annual precipitation and subsequent moisture availability will occur between November and March across the Great Basin.

For arid and semiarid regions of the United States, any discussion of changes in precipitation without referencing variability is incomplete. Changes in the frequency of anomalously wet and dry cool seasons generally adhere to the dipole pattern observed in changes in the mean. For the northern cold deserts, models suggest increased interannual variability in addition to increased cool-season precipitation. This results in an increase in the frequency of wet winters, defined as occurring 1 in every $4 \mathrm{yr}$ in the historical period (the upper 25 th percentile of the distribution), with anomalously wet

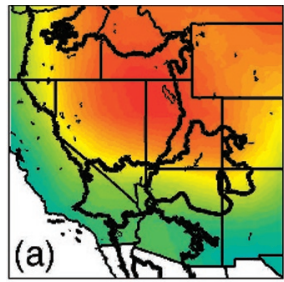
0

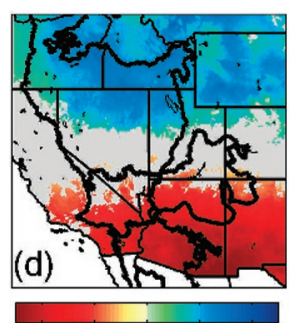

$-20-100 \% 1020$
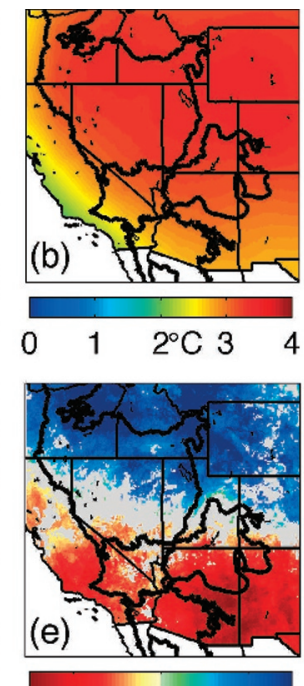

$-50$

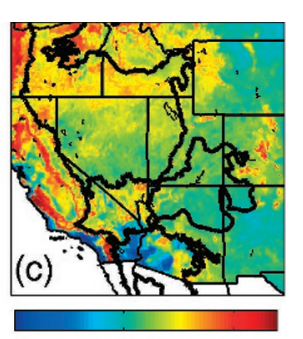

25days 50

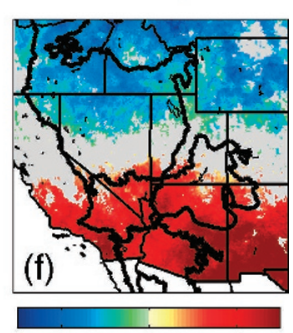

$-50 \quad 0 \% \quad 50$
Figure 2. Multimodel mean projected changes by the mid-21st century (2046-2065) compared to historical conditions (1971-2000) for a, coolseason (November-March) temperature (units: degrees Celsius); b, summer (June-August) temperature (units: degrees Celsius); c, the length of frost-free period (units: days); d, cool-season (NovemberMarch) precipitation (units: percent change); e, frequency of wet coolseason conditions defined by the upper quartile of historic observations (units: percent change); and $\mathbf{f}$, frequency of dry cool-season conditions defined by the lower quartile of historic observations (units: percent change). Values are displayed where at least 9 of the 13 models agree on the sign of the change.

winters occurring $60 \%$ more often across the northern Great Basin by the mid-21st century (Fig. 2e). In contrast, the frequency of wet winters is projected to decrease across the warm deserts, while the likelihood of dry winters (in the lower 25 th percentile of the historical distribution) is projected to increase (Fig. 2f). In addition, the frequency of rainfall events $>2 \mathrm{~mm}$ that occur with minimum temperatures above $0^{\circ} \mathrm{C}$ (implying precipitation as rain rather than snow) is projected to increase $20-50 \%$ over much of the Great Basin (not shown).

\section{Climate Change Influences on Wildfire Danger}

Complementing projected changes in temperature and precipitation, projected changes in fire danger indices exhibit a regionally distinct pattern of increased EFD across much of the interior western United States (Fig. 3a). Results suggest up to an additional $3 \mathrm{wk}$ of EFD over the Sonoran, Mojave, and Colorado deserts, with increases between 1 and $3 \mathrm{wk}$ across the Great Basin. These differences are reflective of an increase in the occurrence of chronic fire seasons. For example, a majority of the models suggest that chronic fire seasons, defined as prolonged EFD conditions that occur on average every fifth year under late 20th century conditions, will occur at least every other year by the mid-21st century over the southern deserts.

The earlier termination in cool-season precipitation promotes a 1-4-wk advancement in the median onset of fire season across the Sonoran, Mojave, and Colorado deserts and Great Basin deserts (Fig. 3b). This is consistent with projected decreases in precipitation and relative humidity over the warm 

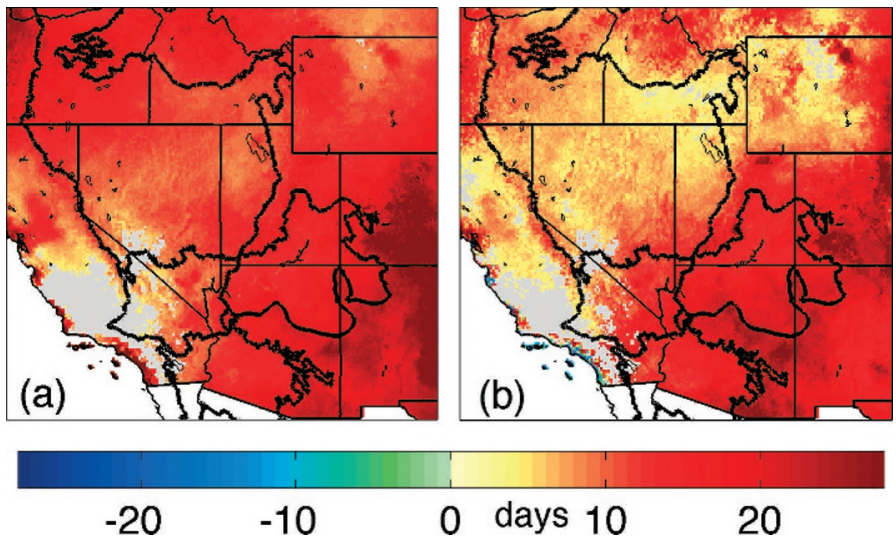

Figure 3. Multimodel mean projected changes by the mid-21st century (2046-2065) compared to historical conditions (1971-2000) in a, number of days with Extreme Fire Danger defined as exceeding the historic 90th-percentile Energy Release Component (ERC) threshold, and b, advance in fire season start date, defined by the first calendar day with 3 consecutive $d$ of exceeding the historic 90th-percentile ERC threshold. Values are displayed where at least 9 of the 13 models agree on the sign of the change.

deserts in early to mid-spring and over the cold deserts in late spring that precede the onset of fire season. By contrast, the models provide little confidence in changes in the end of fire season across the region, typically associated with wetting rains of monsoonal (southern and eastern deserts) and midlatitude (northern deserts) origin. Likewise, projections of fire danger do not provide results suggestive of changes in potential postmonsoonal fire seasons in the southwestern deserts.

\section{DISCUSSION}

Although numerous processes other than climate change may be the driving force behind local invasions, we hypothesize here that climate change represents an additional large-scale pressure that may hasten the rate of change both by increasing the frequency of disturbance catalysts to invasion and producing conditions more conducive to establishment. Model results suggest a number of ways in which physical factors may favor such a scenario: 1) increases in the length of growing season and decrease in episodic cold mortality events, 2) changes in the frequency of moisture anomalies and precipitation type, and 3) increases in the frequency of conditions conducive to large fire potential. We provide a conceptual guideline to how these factors may conspire to increase invasion potential across the deserts of the western United States.

Changes with respect to biophysical thresholds (i.e., $0^{\circ} \mathrm{C}$ threshold) may play an important role in discerning the fate of various invasive annual grasses. For example, cold-intolerant species (e.g., $P$. ciliare) adapted to warmer environments are likely to benefit from the shift in temperature probability distribution, expanding their suitable range north and upward in elevation in the absence of other drivers (Archer and Predick 2008). Likewise, warming and its influence on evapotranspiration may limit species in areas where moisture availability becomes limiting (e.g., Smith et al. 1997). While such results appear straightforward, observations suggest that more complex changes can occur than would be expected on the basis of solely increasing temperatures. For example, Kimball et al. (2010) showed an increased prevalence of cold-adapted winter annuals in the Sonoran Desert over the past several decades in spite of warming, resulting from a delay in the onset of coolseason precipitation from late fall to early winter that promoted the preferential establishment of species that germinate in colder temperatures.

In rain-snow transition elevations, warming is hypothesized to reduce snowpack, making vegetation and soils more vulnerable to freeze-thaw cycles, altering moisture and nutrient dynamics, and modifying species composition (e.g., Harte and Shaw 1995; Inouye 2000; Kreyling 2010). Reduced snowpack in transition elevations associated with a shift in the phase of precipitation from snow to rain may also promote $B$. tectorum invasions and biomass at higher elevations currently limited by short growing seasons (e.g., Chambers et al. 2007). Decreases in winter snow cover in the northern deserts are also posited to increase the number of cohorts of B. tectorum in a warming scenario by increasing the number of rainfall events that occur in the absence of snow cover or frozen soils (e.g., Mack and Pyke 1983). Future deterministic approaches may be needed to resolve the complex response of individual species and community composition to climate change by examining a suite of variables at the necessary time scales (e.g., requirements for germination, survival and establishment, seed production).

Projections for precipitation are likely to bring about differential impacts for invasive annual grasses across the deserts of the western United States because of the strong latitudinal gradient in cool-season moisture variability. Common throughout the study area is an earlier end to cool-season precipitation that, in concert with increased temperature, decreased soil moisture and humidity, was shown to advance the onset date of fire season. For the warm southern deserts, increased aridity and drought frequency (e.g., Seager et al. 2007) may provide an additional edge to drought-adapted nonnative grasses, as it will likely increase native woody vegetation stress and mortality (Miriti et al. 2007) and will likely favor opportunistic winter annual grasses capable of capitalizing on the more sporadic precipitation typical of drought periods. By contrast, for the northern Great Basin, warmer and wetter winters may provide a competitive advantage to $B$. tectorum since it is a fall germinator able to grow rapidly after snowmelt and usurp soil moisture earlier in the year (Upadhyaya et al. 1986).

Changes in variability are also likely to influence ecosystem community structure (e.g., Hereford et al. 2006; Dalgleish et al. 2010). Increases in the frequency of wet winters or epochs may promote the establishment of winter invasive annual grasses and their seed bank across the northern Great Basin, whereas decreases in frequency of wet winters and increases in the length and magnitude of droughts in the southern deserts will place the competitive edge with the species that have the longest seed bank viability. It is important to note that the influence of climate change will be modified by decadal-scale climate variability, which may modify the pace of invasion (e.g., Salo 2005). While the current group of models are not suited for assessing near-term decadal precipitation variability, a new set of 


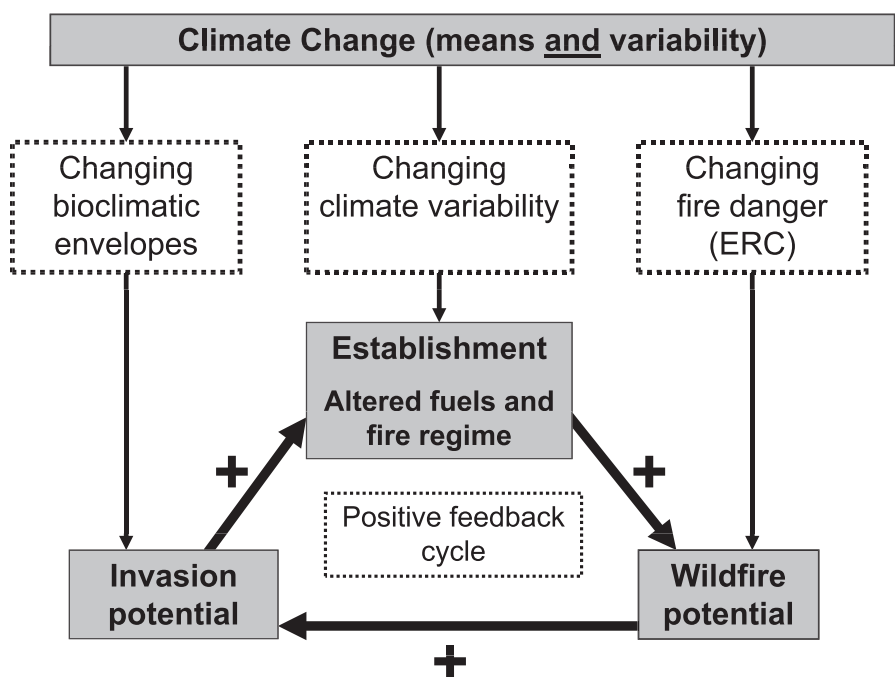

Figure 4. Conceptual representation of how climate will influence wildfire and invasive species in arid and semiarid rangelands of the western United States through each element of a potential positive feedback cycle that sees increased wildfire potential and occurrence, invasion potential, and invasive establishment that subsequently alters fuels and fire regimes.

coordinated experiments developed for the IPCC's fifth assessment report may provide additional insight.

Climate change is hypothesized to be a catalyst in the fireinvasive feedback loop in the deserts of the western United States (Fig. 4). Increased fire frequency and extent will likely promote the invasion fronts of annual grasses into previously uninvaded areas. Increased annual grass cover and abundance will lead to more extensive and severe wildfires, proliferating the cycle, particularly when coupled with other climate-induced mechanisms (e.g., B. tectorum capitalizes on increased fall/ winter precipitation, earlier snowpack melt, decreased water availability in summer in the Great Basin). We hypothesize that an earlier fire season will preferentially burn in fuels that cure earlier in the year, such as B. tectorum, thereby promoting a modified fire regime. The positive feedback loop suggests the potential for nonlinearity in ecosystem behavior (e.g., Logan et al. 2003) due to changes in critical biophysical thresholds and disturbance regimes.

\section{Suggestions for Incorporating a Coupled Approach to Modeling} Bradley et al. (2009) used bioclimatic envelope modeling with a suite of GCMs to create a set of projected ranges in invasive species. These projections provide guidance on the climatic suitability of a given species and highlight changes in potential range expansion and contraction under future climate normals. While bioclimatic models may project potential species distributions under climate change, mechanisms through which species advance and retract to the potential suitable habitat are not accounted for. To complement climate suitability maps, effort should be taken to include mechanistic modeling that incorporates higher-order climate statistics, such as climate variability, key biophysical thresholds, and wildfire potential, that facilitate invasibility. Areas where future climate suitability and mechanisms that assist in invasion align may then be considered at highest risk of invasion. Conversely, current land cover is less likely to be invaded in areas with lower risk of catalysts.

There are three key additions that we suggest should be considered when developing new coupled approaches:

Higher-Order Climate Statistics. In arid and semiarid landscapes, variability in moisture availability and timing, ranging from precipitation events to drought or pluvial epochs, may facilitate or inhibit the spread of a species (e.g., Mack and Pyke 1983). Deterministic approaches capable of incorporating higher-order climate statistics to model population biology may provide information on future invasion fronts to complement climatic suitability projections (Bradley et al. 2010).

Disturbance. Disturbance (e.g., wildfire) is a critical component missing from most current modeling efforts. The likelihood of both initial and repeat disturbance characterizes which areas are more susceptible to invasion through a fireinvasive feedback loop, ultimately resulting in a transition to a new ecological state (Bestelmeyer et al. 2003).

Probabilistic. Climate change adaptation plans should account for a range of scenarios from combinations of changes in climate and management practices. A probabilistic-based approach can provide insight into what impacts are most likely that can then be used in decision support systems to guide management directives and policies.

\section{MANAGEMENT IMPLICATIONS}

Management and mitigation of invasive annual grasses over the 21st century require actions that not only address where species can thrive but also pay heed to the mechanisms that will get them there. To date, estimates of the spread of invasive species, particularly annual grasses, have been accomplished through projecting ecological niches with climate projections. While management may not be able to alter long-term changes in climate, climate variability provides trigger points at which management actions can mitigate the potential invasives trajectory through responding to mechanisms and initiate a different trajectory toward maintaining native or other desired ecotypes. For example, while temperatures are predicted to warm across the deserts of the western United States, winters in which temperatures drop below freezing for several consecutive days may be good years for management to scale up eradication programs of weakened cold-intolerant invasive species. Likewise, a pluvial winter may produce an abundance of annual grasses while also raising fuel moistures in desirable natives, and prescribed fire programs may be able to capitalize on windows of opportunity for burning tracts of invasive annual grasses without damaging succulent native species. Projected increases in the frequency and onset of extreme fire danger across the region will likely dramatically increase mortality rates of native species less adapted to wildfire and make proactive reduction of invasive fuel loads all the more important.

Climate change information needs to be delivered on scales and in a format readily accessible to management. Examining changes in climate through not only changes in the means but also higher-order climate statistics is a critical component in 
formulating effective approaches to management and mitigation of invasive annual grasses in the deserts of the western United States. The ability to implement climate literacy alongside management-driven tools to address contemporary climate on invasive annual grass species treatment and wildfire is needed to proactively address management actions needed to mitigate future impacts. Finally, it is critical to recognize and quantify confidence intervals for aspects of regional climate change, as management efforts can be optimally invested in locales where model agreement is high and potential impacts are pronounced.

\section{ACKNOWLEDGMENTS}

The authors wish to thank Julio Betancourt for his excellent insights at early stages of this work as well as valuable constructive feedback from two anonymous reviewers and the associate editor. This research was supported National Science Foundation awards EPS-0814387 and ATM-0801474. GCM data were obtained from WCRP CMIP3 multimodel data set courtesy of the Program for Climate Model Diagnosis and Intercomparison.

\section{LITERATURE CITED}

Abatzoglou, J. T., and T. J. Brown. 2009. 8-km historical datasets for FPA. Reno, NV, USA: Desert Research Institute. CEFA Report 09-04. Available at: http:// cefa.dri.edu/Publications/FPA_8km_historical_report.pdf. Accessed 31 July 2011.

Abatzoglou, J. T., and T. J. Brown. 2011. A comparison of statistical downscaling methods suited for wildfire applications. International Journal of Climatology (in press). doi:10.1002/joc.2312

Adams, H. D., M. Guardiola-Claramonte, G. A. Barron-Gafford, J. C. Villegas, D. D. Breshears, C. B. Zou, P. A. Troch, and T. E. Huxman. 2009. Temperature sensitivity of drought-induced tree mortality portends increased regional dieoff under global-change-type drought. Proceedings of the National Academy of Sciences 106:7063-7066.

Archer, S. R., AND K. I. Predick. 2008. Climate change and ecosystems of the southwestern United States. Rangelands 30(3):23-28. doi: 10.2111/1551$501 X$

Bestelmeyer, B. T., J. R. Brown, K. M. Havstad, R. Alexander, G. Chavez, and J. E. HerRick. 2003. Development and use of state-and-transition models for rangelands. Journal of Range Management 56:114-126.

Betancourt, J. L. 2007. From fireproof desert to flammable grassland: buffelgrass invasion in the Sonoran desert. Eos Transactions AGU 88(52), Fall Meeting Supplement, Abstract B34A-02.

Bradley, B. A. 2009. Regional analysis of climate change on cheatgrass invasion shows potential risk and opportunity. Global Change Biology 15:196-208.

Bradley, B. A., D. M. Blumenthal, D. S. Wilcove, and L. H. Ziska. 2010. Predicting plant invasions in an era of global change. Trends in Ecology and Evolution 25(5):310-318.

Bradley, B. A., AND J. F. MustaRd. 2005. Identifying land cover variability distinct from land cover change: cheatgrass in the Great Basin. Remote Sensing of the Environment 94:204-213.

Bradley, B. A., D. S. Wilcove, and M. Oppenheimer. 2009. Climate change and plant invasions: restoration opportunities ahead? Global Change Biology 15:1511-1521. doi: 10.1111/j.1365-2486.2008.01824.x

BrooKs, M. L., AND K. BerRY. 1999. Ecology and management of alien annual plants in the California deserts. CalEPPC News 7(3/4):4-6.

Brooks, M. L., C. M. D’Antonio, D. M. Richardson, J. B. Grace, J. E. Keeley, J. D. Ditomaso, R. J. Hobbs, M. Pellant, and D. Pyke. 2004. Effects of invasive alien plants on fire regimes. BioScience 54(7):677-688.

Brooks, M. L., And T. C. Esque. 2002. Alien grasses in the Mojave and Sonoran Deserts. In: M. Kelly, M. Howe, and B. Neill [EDS.]. Proceedings California
Exotic Plant Pest Council Symposium 15-16 October 1999; Sacramento, CA, USA. San Diego, CA, USA: California Exotic Plant Pest Council. p. 39-44.

Brooks, M. L., AND J. R. MATCHEtT. 2006. Spatial and temporal patterns of wildfires in the Mojave Desert, 1980-2004. Journal of Arid Environments 67:148-164.

Chambers, J. C., B. A. Roundy, R. R. Blank, S. E. Meyer, and A. Whittaker. 2007. What makes Great Basin ecosystems invasible by Bromus tectorum? Ecological Monographs 77(1):117-145.

Dalgleish, H. J., D. N. Koons, and P. B. Adler. 2010. Can life history traits predict the vulnerability of forb populations to increased climate variability? Journal of Ecology 98:209-217.

Deeming, J. E., R. E. Burgan, and J. D. Cohen. 1977. The National Fire Danger Rating System—1978. Ogden, UT, USA: USDA Forest Service Intermountain Forest and Range Experiment Station. General Technical Report INT-39. 63 p.

Diffenbaugh, N. S., F. Giorgi, and J. S. Pal. 2008. Climate change hotspots in the United States. Geophysical Research Letters 35, L16709. doi: 10.1029/ 2008GL035075

Ditomaso, J. M., M. L. Brooks, E. B. Allen, R. Minnich, P. M. Rice, and G. B. Kyser. 2006. Control of invasive weeds with prescribed burning. Weed Technology 20:535-548.

Harte, J., and R. Shaw. 1995. Shifting dominance within a montane vegetation community results of a climate-warming experiment. Science 267:876-880.

Hereford, R., R. H. Webb, and C. I. Longpre. 2006. Precipitation history and ecosystem response to multidecadal precipitation variability in the Mojave Desert region, 1893-2001. Journal of Arid Environments 67:13-34. doi: 10.1016/j.jaridenv.2006.09.019

HumpHREY, R. R. 1974. Fire in the deserts and desert grassland of North America. In: T. T. Kozlowski and D. E. Ahlgren [EDs.]. Fire and ecosystems. New York, NY, USA: Academic Press. p. 354-400.

INOUYE, D. W. 2000. The ecological and evolutionary significance of frost in the context of climate change. Ecology Letters 3:457-463.

[IPCC] Intergovernmental Panel on Climate Change. 2007. Climate change 2007: the physical science basis. Contribution of Working Group I to the Fourth Assessment Report of the Intergovernmental Panel on Climate Change, S. Solomon, et al. [EDs.]. Cambridge, United Kingdom: Cambridge University Press. 996 p.

KeELEY, J. E. 2006. Fire management impacts on invasive plants in the western United States. Conservation Biology 20:375-384.

Kimball, S., A. L. Angert, T. E. Huxman, and D. L. Veneble. 2010. Contemporary climate change in the Sonoran Desert favors cold-adapted species. Global Change Biology 16:1555-1565. doi: 10.1111/j.1365-2486.2009.02106.x

Kolden, C. A., And T. J. Brown. 2010. Beyond wildfire: perspectives of climate, managed fire and policy in the USA. International Journal of Wildland Fire 19:364-373.

KREYLING, J. 2010. Winter climate change: a critical factor for temperate vegetation performance. Ecology 91:1939-1948. doi: 10.1890/09-1160.1

Kriticos, D. J., ANd A. Leriche. 2010. The effects of climate data precision on fitting and projecting species niche models. Ecography 33:115-127. doi: 10.1111/ j.1600-0587.2009.06042.x

Launchbaugh, K., B. Brammer, M. Brooks, S. Bunting, P. Clark, J. Davison, M. Fleming, R. Kay, M. Pellant, D. A. Pyke, and B. Wylie. 2008. Interactions among livestock grazing, vegetation type, and fire behavior in the Murphy Wildland Fire Complex in Idaho and Nevada, July 2007. Reston, VA, USA: US Geological Survey. US Geological Survey Open-File Report 2008-1214. 42 p.

Logan, J. A., J. Regniere, and J. A. Powell. 2003. Assessing the impacts of global warming on forest pest dynamics. Frontiers in Ecology and the Environment 1:130-137.

Mack, R. N. 1981. Invasion of Bromus tectorum L. into western North America: an ecological chronicle. Agro-Ecosystems 7(2):145-165.

Mack, R. N., AND D. A. PYkE. 1983. The demography of Bromus tectorum: variation in time and space. Journal of Ecology 71:69-93.

Melgoza, G., R. S. Nowak, And R. J. Tausch. 1990. Soil water exploitation after fire: competition between Bromus tectorum (cheatgrass) and two native species. Oecologia 83(1):7-13.

Mensing, S., S. Livingston, and P. Barker. 2006. Long-term fire history in Great Basin sagebrush reconstructed from macroscopic charcoal in spring 
sediments, Newark Valley, Nevada. Western North American Naturalist 66:64-77.

Miriti, M. N., S. Rodgriguez-Buritica, S. J. Wright, and H. F. Howe. 2007. Episodic death across species of desert shrubs. Ecology 88:32-36.

Mote, P. W., A. F. Hamlet, M. P. Clakk, and D. P. Lettenmaier. 2005. Declining mountain snowpack in western North America. Bulletin of the American Meteorological Society 86:39-49.

Pearson, R. G., and T. P. Dawson. 2003. Predicting the impacts of climate change on the distribution of species: are bioclimatic envelope models useful? Global Ecology and Biogeography 12(5):361-371.

Rehfeldt, G. E., N. L. Crookston, M. V. Warwell, and J. S. Evans. 2006. Empirical analysis of plant-climate relationships for the western United States. International Journal of Plant Sciences 167:1123-1150.

ReICHLER, T., AND J. KIM. 2008. How well do coupled models simulate today's climate? Bulletin of the American Meteorological Society 89:303-311.

Ricketts, T., E. Dinerstein, D. Olson, C. Loucks, W. Eichbaum, D. Dellsala, K. Kavanagh, P. Hedao, P. Hurley, K. Carney, R. Abell, and S. Walters. 1999. Terrestrial ecoregions of North America: a conservation assessment. Washington, DC, USA: Island Press. $424 \mathrm{p}$.

Sal0, L. F. 2005. Red brome (Bromus rubens subsp. madritensis) in North America: possible modes for early introductions, subsequent spread. Biological Invasions 7:165-180.

Scheffer, M., J. Bascompte, W. A. Brock, V. Brovkin, S. R. Carpenter, V. Dakos, H. Held, E. H. Van Nes, M. Rietkerk, and J. Sugihara. 2009. Early warning signals for critical transitions. Nature 461:53-59.

Schmid, M. K., And G. F. Rogers. 1988. Trends in fire occurrence in the Arizona upland subdivision of the Sonoran Desert, 1955 to 1983. The Southwestern Naturalist 33(4):437-444.

Seager, R., M. F. Ting, I. M. Held, Y. Kushnir, J. Lu, G. Vecchi, H.-P. Huang, N. Harnik, A. Leetmaa, N.-C. Lau, C. LI, J. Velez, and N. Naik. 2007. Model projections of an imminent transition to a more arid climate in southwestern North America. Science 316:1181-1184.

Smith, S. D., R. K. Monson, and J. E. Anderson. 1997. Physiological ecology of North American desert plants. New York, NY, USA: Springer-Verlag. 286 p.

Swetnam, T. W., C. D. Allen, and J. L. Betancourt. 1999. Applied historical ecology: using the past to manage for the future. Ecological Applications 9:1189-1206.

Swetnam, T. W., and J. L. Betancourt. 1990. Fire-Southern Oscillation relations in the southwestern United States. Science 249. doi: 10.1126/science.249. 4972.1017

Upadhyaya, M. K., R. Turkington, and D. Mcllvkide. 1986. The biology of Canadian weeds. 75. Bromus tectorum L. Canadian Journal of Plant Science 66:689-709.

Ward, J. P., S. E. Smith, and M. P. McClaran. 2006. Water requirements for emergence of buffelgrass (Pennisetum ciliare). Weed Science 54(4):720-725.

Weiss, J. L., C. L. Castro, and J. T. Overpeck. 2009. Distinguishing pronounced droughts in the southwestern United States: seasonality and effects of warmer temperatures. Journal of Climate 22:5918-5932.

WeISS, J. L., AND J. T. OVERPECK. 2005. Is the Sonoran Desert losing its cool? Global Change Biology 11:2065-2077. doi: 10,1111/j.1365-2486.2005.01020.x

Westerling, A. L., H. G. Hidalgo, D. R. Cayan, and T. W. Swetnam. 2006. Warming and earlier spring increase western US forest wildfire activity. Science 313:940-943

Whisenant, S. G. 1990. Changing fire frequencies on Idaho's Snake River Plains: ecological and management implications. In: E. D. McArthur, E. M. Romney, S. D. Smith, and P. T. Tueller [EDS.]. Symposium on cheatgrass invasion, shrub die-off and other aspects of shrub biology and management. Ogden, UT, USA: US Department of Agriculture, Forest Service. General Technical Report INT-276. p. 4-10.

WILcoX, B. P., AND T. L. ThuRow. 2006. Emerging issues in rangeland ecohydrology: vegetation change and the water cycle. Rangeland Ecology \& Management $59: 220-224$ 